\title{
COMMERCIAL PRODUCTION OF GLOBE ARTICHOKE (CYNARA SCOLYMUS L.) IN-VITRO
}

\author{
EL-ZEINY, O.A.H. ${ }^{1}$, U.A. EL-BEHAIRY ${ }^{2}$, G. ZOCCHI ${ }^{3}$ AND M.M. RASHWAN ${ }^{2}$ \\ 1. Veg. Res. Deps., Hort. Res. Inst. , ARC, Dokki, Giza, Cairo. \\ 2. Hort. Dep., Faculty of Agriculture, Ain Shams University, Cairo. \\ 3. Plant Production Dep., Faculty of Agriculture, Milan University, Italy
}

( Manuscript received 26 December 2012 )

\begin{abstract}
This work was carried out in the Laboratory of tissue culture Arid Land Agriculture Research Unit (ALARU) Faculty of Agriculture Ain Shams University during the two autumn seasons of 2006 and 2008 in two separated experiments. First: Micropropagation of globe artichoke (Cynara scolymus L.).Second: Acclimatization of plantlets produced from tissue culture condition to the open field.

First experiment: data cleared that there is a relationship between the size of shoot-tip and the percentage of survival regenerated and the time needed to regenerate shoots however increasing the size of shoot tip explants from 2 to $5 \mathrm{~cm}$ led to a gradual increase in both survival and regenerated shoot percentage. And at the same time reduce the number of days needed to configured healthy shoots. Culturing the shoot tips explants in the media containing the ascorbic acid or citric acid led to a reduction of browning percentage.

Increasing the levels of both cytokinins (BA and $\mathrm{Kn}$ ) from 2.5 to $10.0 \mathrm{mg} / \mathrm{L}$ was sufficient to enhance the capability of explants to produce more shoots especially at high level but unfortunately the highest level of both cytokinins $(10.0 \mathrm{mg} / \mathrm{L})$ led to obtain callus formation beside shoots production which is undesirable.

There are relationship between number of subculture and rates of shoots productions. Increasing the number of subcultures till fifth times increased gradually the number of shoot production and decreased shoot length.

IBA added to the media for rooting the regenerated shoots encouraged the root formation (number and length|) than IAA treatments. On the other side addition of activated charcoal to the nutrient media is very important for enhancement root formation.

Concerning of the second experiment (acclimatization) data reported that culturing the plantlets produced from tissue culture in pots contained vermiculite either alone or in combination with other compounds gave the highest transplants survival percentage $(60-90 \%)$ than other substrate treatments.
\end{abstract}




\section{INTRODUCTION}

The globe artichoke (Cynara scolymus L.) which belongs to the family Compositae is considered one of the important vegetable crops grown in Egypt for local consumption and exportation. Artichoke is usually vegetatively propagated by crown division or offshoots because plants grown from seeds generally lack uniformity (Ibrahim et. al. 1981, Welbaum 1994). Traditional propagation usually enunciated with spread of diseases and develops a phytopathogenic situation which is hard to control since field-grown plants can be easily attacked by several pathogen agents such as viruses bacteria fungi nematodes and insects. However in vitro culture allows the production of disease- free-plants which are of great value to artichoke growers (Rossi and De-Paoli 1992).

The use of tissue culture methods is expected to help in solving some problems of genetic improvement in the globe artichoke and the practices of cultivation primarily by facilitating the production of healthy material and quicker multiplication (Ancora 1986). Moreover the absence of pathogens in the micro propagated plants could however be sufficient reason to justify better plant growth and hence a better yield. Browning of tissue is most severe in species that contain high levels of tannins or other hydroxyphenols. The browning results from the action of copper containing oxidase enzymes (e.g. polyphenoloxidaae and tryosinase) which are synthesized and/ or released due to wounding during the excision and sterilization of the tissue (Lerch 1981, Torres 1989). However the browning of tissue can be prevented by removing the phenolic compounds, modifying the redox potential, activating the phenolase enzymes and reducing the phenolase activity and/or substrate availability (Anderson et. al. 1982, Ammirato 1983). Nevertheless ascorbic acid and citric acid are the most commonly used as antioxidants and generally used at concentrations of 50-150 mg/l (Ancora 1986, Torres 1989)

In general the tissue culture micro propagation besides favoring restoration and genetic improvements of the cultivated varieties could lead to a worldwide increase in cultivation area.

Micro propagation techniques has many advantage therefore tissue culture technique was applied to evaluate its feasibility for a wider use. However through micro propagation different variation could be done in plantlets morphology these variants pose a problem for production of uniform true to type plants.

Therefore the objective of this work was undertaken to establish a rapid method of in vitro micropropagation for globe artichoke plantlets derived from in vitro conditions and compare to the field - derived - plants. 


\section{MATERIALS AND METHODS}

This work was carried out in the Laboratory of tissue culture Arid Land Agriculture Research Unit (ALARU) Faculty of Agriculture Ain Shams University during the two autumn seasons of 2006 and 2008 in two separated experiments. First: Micropropagation of globe artichoke (Cynara scolymus L.).Second: Acclimatization of plantlets produced from tissue culture conditions to the open field.

\section{First Experiment Micro propagation}

\section{1- Plant material}

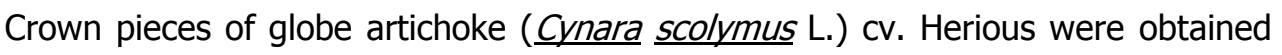
from Horticulture Research Institute Agriculture Research Center Giza Egypt. These pieces were planted during the two autumn seasons of 2006 and 2008 in the open field of the Fucalty of Agriculture Ain Shams Universityin . All agricultural practices were used according to the recommendations of the Ministry of Agriculture. The new produced plants were used as the source of meristems materials needed for tissue culture study.

The main vegetative off shoots were obtained from the growing mother plants. These offshoots were collected in mid of March according to the method of Bekheet (1992). The shoots were washed under running tap water for 30 minutes and surface sterilized using $70 \%$ ethanol for $5 \mathrm{sec}$ and $2 \%$ sodium hypochlorite for 20 min with two drops of a surfactant "Tween 20" were added. Shoot tips were excising at about $10 \mathrm{~cm}$ in length and culturing inside the Laminar Flow Hood and placed on the nutrient media.

\section{2- Nutrient media}

The basal nutrient media used in this experiment contained macro and microelements according to Murashige \& Skoog (1962) which known as (M\&S) medium supplemented with $5.0 \mathrm{mg} / \mathrm{L} \mathrm{kn}$ plus IAA at $0.5 \mathrm{mg} / \mathrm{L}$. The $\mathrm{pH}$ of the media was adjusted at $5.7 \pm 0.1$ before the addition of agar. The media were distributed into culture tubes where each tube contained $15 \mathrm{~cm}$ and sterilized by autoclaving at $121^{\circ} \mathrm{C}$ for $15 \mathrm{~min}$.

\section{3- - Treatments}

\section{(A) - Establishment stage}

\section{a- Size of explants}

Shoot tip explants were excised inside the laminar Flow Hood at three sizes 23 and $5 \mathrm{~mm}$. All explants were excised on the same day and placed on the previous nutrient media. Data were recorded in the survival percentage (\%) Percentage of shoot formation (\%) and the number of days to configured branches. 


\section{b-Prevent the formation of browning}

To prevent the browning formation in shoot tip explants the excised shoot tips $(5 \mathrm{~mm})$ were immersed for 30 second in a sterilized solution of the following contents:

1- Ascorbic acid (150 mg/l)

2- Citric acid (150 mg/L)

3)-Solution of ascorbic acid $150 \mathrm{mg} \mathrm{mg} / \mathrm{l}+$ Citric acid (150 mg/l.

After that the treated shoot tip explants were cultured on the previous nutrient media of M\&S. Data were recorded in the browning percentage (\%) after 4 weeks from culturing.

\section{(B) - Multiplication stage}

\section{Shoot formation}

\section{a- Effect of cytokinins}

Two different cytokinins i.e. kinitein (kn) and Benzyladenine (BA) were examined and added to M\&S media at the concentrations of 0.0 (control) 2.55 .0 and 10.0 $\mathrm{mg} / \mathrm{L}$. Data about number of shoots and shoot length were recorded after 4 weeks from cultured the shoot tips.

\section{b- Number of subculture}

This experiment was conducted to study the effect of consecutive subcultures on the number of shoot production. Shoot tips (5 $\mathrm{mm}$ in length) were cultured on jars containing $50 \mathrm{ml}$ of M\&S medium supplemented with $5 \mathrm{mg} / \mathrm{L} \mathrm{kn}$ plus $0.5 \mathrm{mg} / 1$ IAA. The numbers and length of proliferated shoots were recorded after 4 weeks from culturing (first sub-culture). Shoots obtained from the first subculture were divided and cultured for another 4 weeks on the same previous fresh medium (second sub-culture). Seven sub-cultures being carried out in this experiment.

\section{c- Root formation}

\section{a- Effect of auxins}

Uniform shoots ( $5 \mathrm{~cm}$ in length) obtained from the previous experiments were transferred to jars containing $50 \mathrm{ml}$ medium consisted of half concentration of M\&S medium plus different concentrations of two types of auxins i.e. IBA and IAA at the concentrations of 0.51 .0 and $2.0 \mathrm{mg} / \mathrm{l}$ for each to study the best auxins and concentrations which encouraged root formation (number and length).

\section{b- Effect of activated charcoal}

Uniform shoots ( $5 \mathrm{~cm}$ in length) obtained from the previous experiments were transferred to jars $(120 \times 60 \mathrm{~mm})$ containing $50 \mathrm{ml}$ medium consisted of half 
concentration of M\&S medium plus $2.0 \mathrm{mg} / \mathrm{L}$ IBA in addition of 0.5 and $1.0 \mathrm{~g} / \mathrm{L}$ activated charcoal to determine the effect of charcoal on root formation.

\section{4- Culture conditions}

All cultures were kept at constant temperature for $26 \pm 2 \mathrm{C}$ and sufficient fluorescent light of 1500 Lux for 16 hours photoperiod.

\section{Second experiment Acclimatization}

The most important stage in tissue culture is transferring plantlets from the aseptic cultural environment to the free-living environment and ultimately to the field. However acclimatization has been defined as process by which in vitro the plantlets adapts to environmental change. This process is necessary because in vitro- derived plantlets are neither adapted nor suited for in vivo conditions. Therefore this experiment was conducted to study the optimal transplanting medium for in vitro derived globe artichoke plantlets. The in vitro derived plantlets about $5 \mathrm{~cm}$ in height were washed with current tap water and then disinfected by immersion in fungicide solution (topsin $1 \mathrm{~g} / \mathrm{l}$ ) and transferred to plastic pots $(7.5 \times 10.5 \mathrm{~cm}$.) containing one of the different media as following:

1. Peat moss.

2. Vermiculite.

3. Washed sand.

4. Peat. moss + washed sand (1:1).

5. Peat moss + Vermiculite $(1: 1)$.

6. Vermiculite + washed sand $(1: 1)$.

7. Peat moss + Vermiculite + washed sand (1:1:1).

Each treatment consisted of 20 pots. Each pot contained one plantlet. Pots were then transferred to the greenhouse and covered with polyethylene sheets to maintain high relative humidity around plants. In addition spraying with water under the plastic sheets was carried out daily while the irrigation took place 3 times a week. Surviving plants were recorded after 4 weeks from transplanting.

\section{5- Statistical analysis}

Data were subjected to proper statistical analysis of variance procedure and means compared using the L.S.D. method at $5 \%$ level of significance according to Snedicor and Cochran (1980).

\section{RESULTS AND DISCUSSION}

First Experiment: Micro propagation

\section{(A)- Establishment stage}




\section{a- Size of explants}

Results Indicate that there is a relationship between the size of shoot-tip and the percentage of survival regenerated shoots and the time needed to regenerate shoots as shown in Fig (1) however increasing the size of shoot tips led to a gradual increase in both survival and regenerated shoot percentage. And at the same time reduce the time needed to configured healthy shoots. Torres (1989) mentioned that the development rate of shoot tip explants was increased gradually with time but this rate was higher with increasing the size of shoot tip explants and vice versa. He also added that change the size of explants changes the levels of carbohydrates proteins and growth substances in the stock plant thus subsequently affecting the response of the explants in vitro.
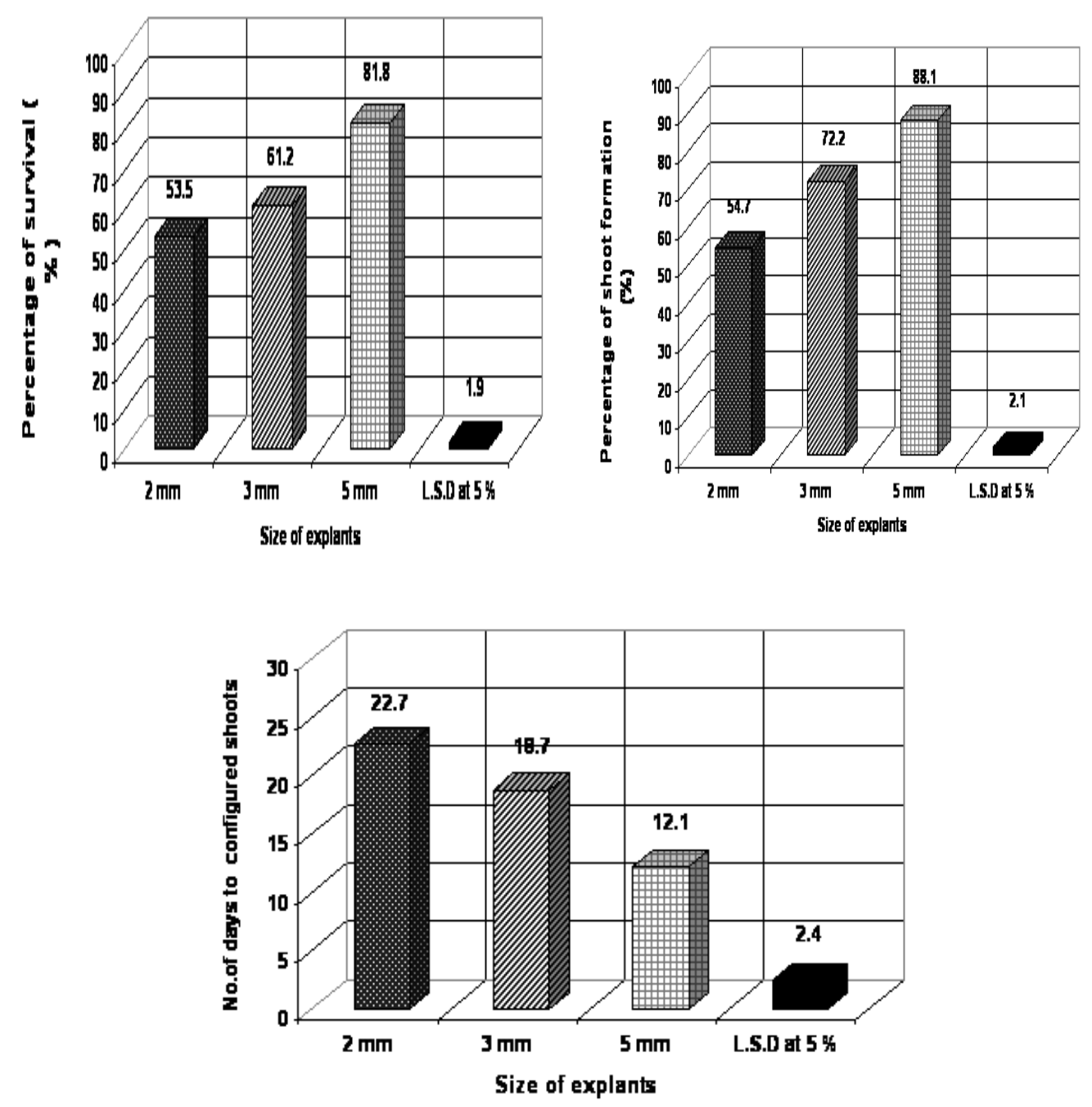

Fig. 1 Effect of the size of shoot tip explants on the percentage of survival regenerated shoots and the time needed to configured shoots 


\section{b-Prevent the formation of browning}

It is clear from Fig.(2) that culturing the shoot tips explants in the media containing the two organic acids used in this experiment led to a reduction of browning percentage especially when these organic acids combined together compared with the medium free from the organic acids (control treatment) or used both of them alone. These results are in accordance with those obtained by (Ancora et. al. 1981) and (Ancora 1986, Torres 1989) who mentioned that ascorbic acid and citric acid are the most commonly used as antioxidants and preventing browning.

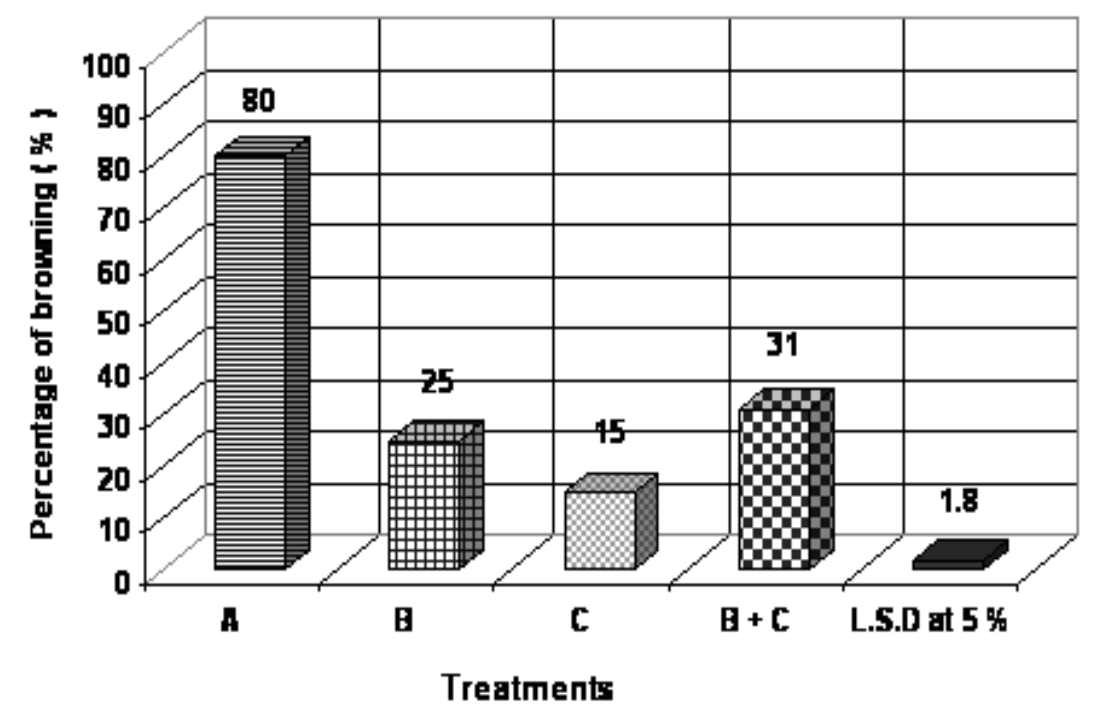
A: Control treatment
B: Ascorbic acid
C: Citric acid

Fig. 2. Effect of ascorbic acid and citric acid treatments on browning percentage in globe artichoke shoot tips cultured in vitro

\section{2- Multiplication stage}

\section{A- Shoot formation}

\section{a- Effect of cytokinins}

Multiple shoot formation rates varied with both concentrations and type of cytokinins (Fig 3). Increasing the levels of both cytokinins (BA and $\mathrm{Kn}$ ) were sufficient to enhance the capability of explants to produce more shoots than control treatment .But Unfortunately the highest level of both cytokinins $(10.0 \mathrm{mg} / \mathrm{L}$ ) led to obtain callus formation beside shoots production which is undesirable. Some previous researchers supported results of our present experiment that there was direct relationship between the higher concentrations of cytokinins and the enhancement of shoots number. However presence of cytokinins in the media depressed the apical 
dominance and consequently activated the axillary's buds which increase the opportunity to proliferate. Thus raising the concentrations of cytokinins increased the bud proliferation and the formation of multi apexes plantlets (Torres (1989).). On the other side BA was significantly surpassed $\mathrm{Kn}$ in the number of shoots production (Fig. 3) These results coincided with Alphonse et al.(2002) on globe artichoke and El-Zeiny (1997 \& 2002) on tomato and pepper respectively. But the contrary Kn treatments produced the longest shoots than the BA application as shown in Fig (6). these results were in agreement with some previous work (Anderson et al 1982 on strawberry Alphonse et. al. (2002) on glob artichoke and El- Zeiny (1997) and (2002) on tomato and pepper respectively.

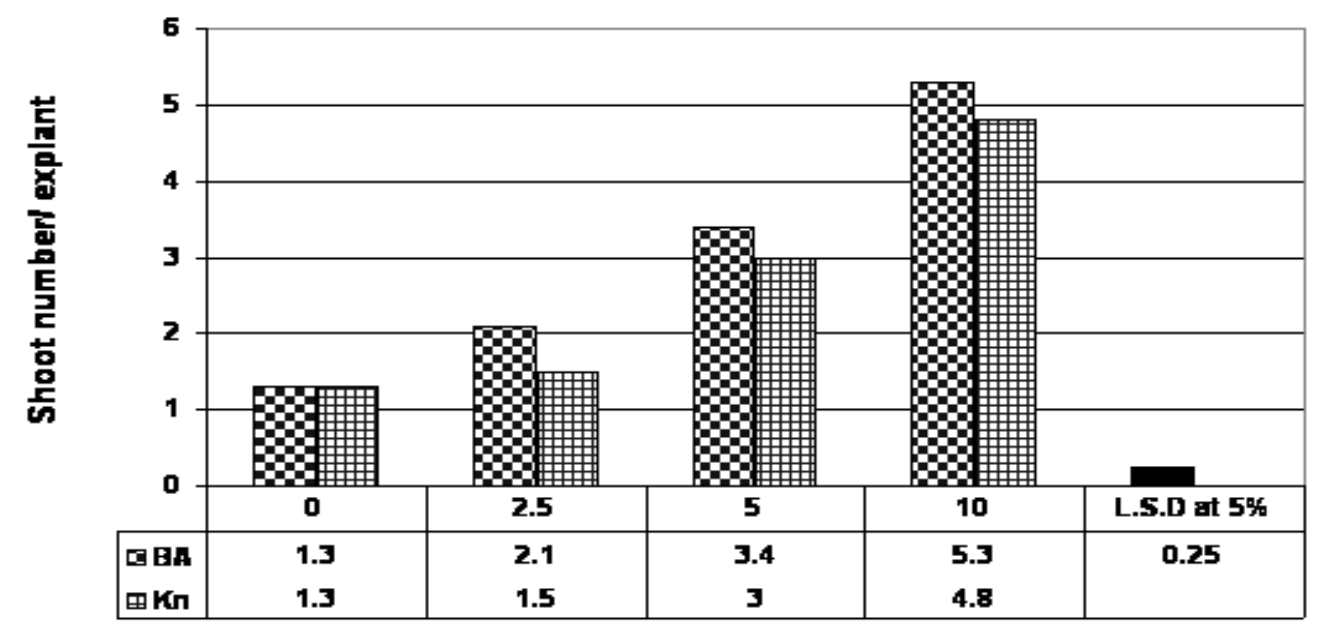

Concentrations ( $\mathrm{mg} / \mathrm{L}$ )

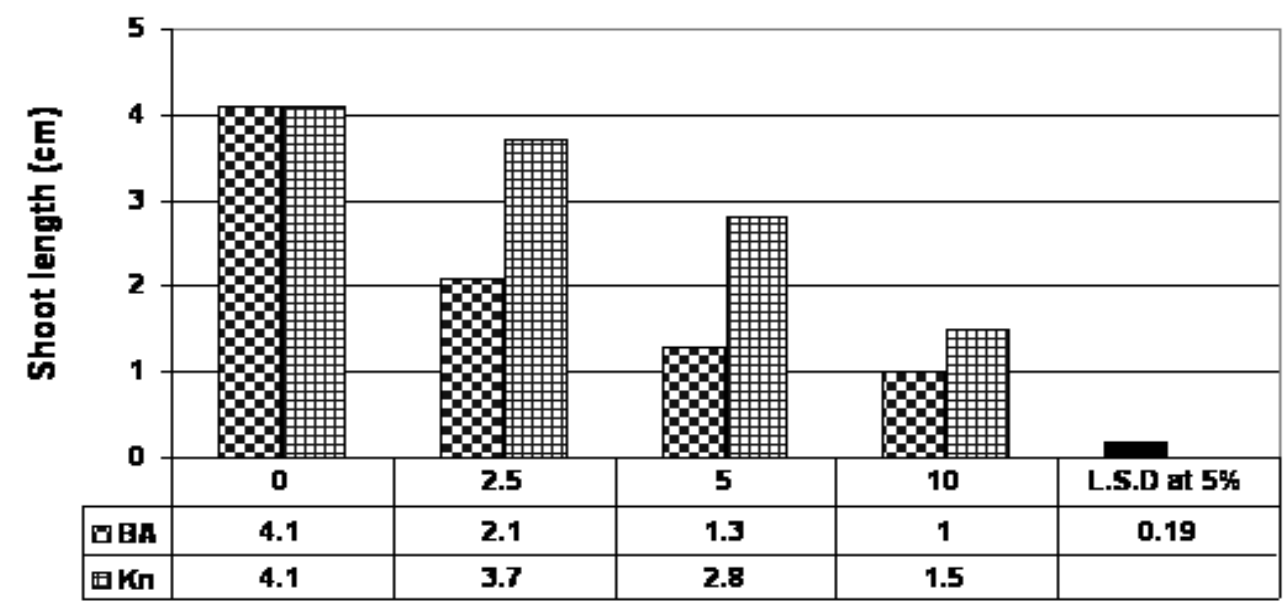

Concentrations ( $\mathrm{mg} / \mathrm{L})$

Fig 3. Effect of cytokinins on shoot number and shoot length production of globe artichoke developed from shoot tips culture. 


\section{b- Number of subculture}

Data in Fig (4) showed that there are relationship between number of subculture and rates of shoots productions. Increasing the number of subcultures till fifth times increased gradually the number of shoot production and decrease shoot length. Multiple shoot formation rates declined eventually with increase in the number of subcultures in all treatments. So the best number of shoot production was obtained after culturing the shoot tips of global artichoke five times in the nutrient media containing $\mathrm{Kn}$ at $5.0 \mathrm{mg} / \mathrm{L}$ plus $0.5 \mathrm{mg} / 1 \mathrm{IAA}$. These results were agreement with Ordas et. al. (1990) and Mehrez (1998)
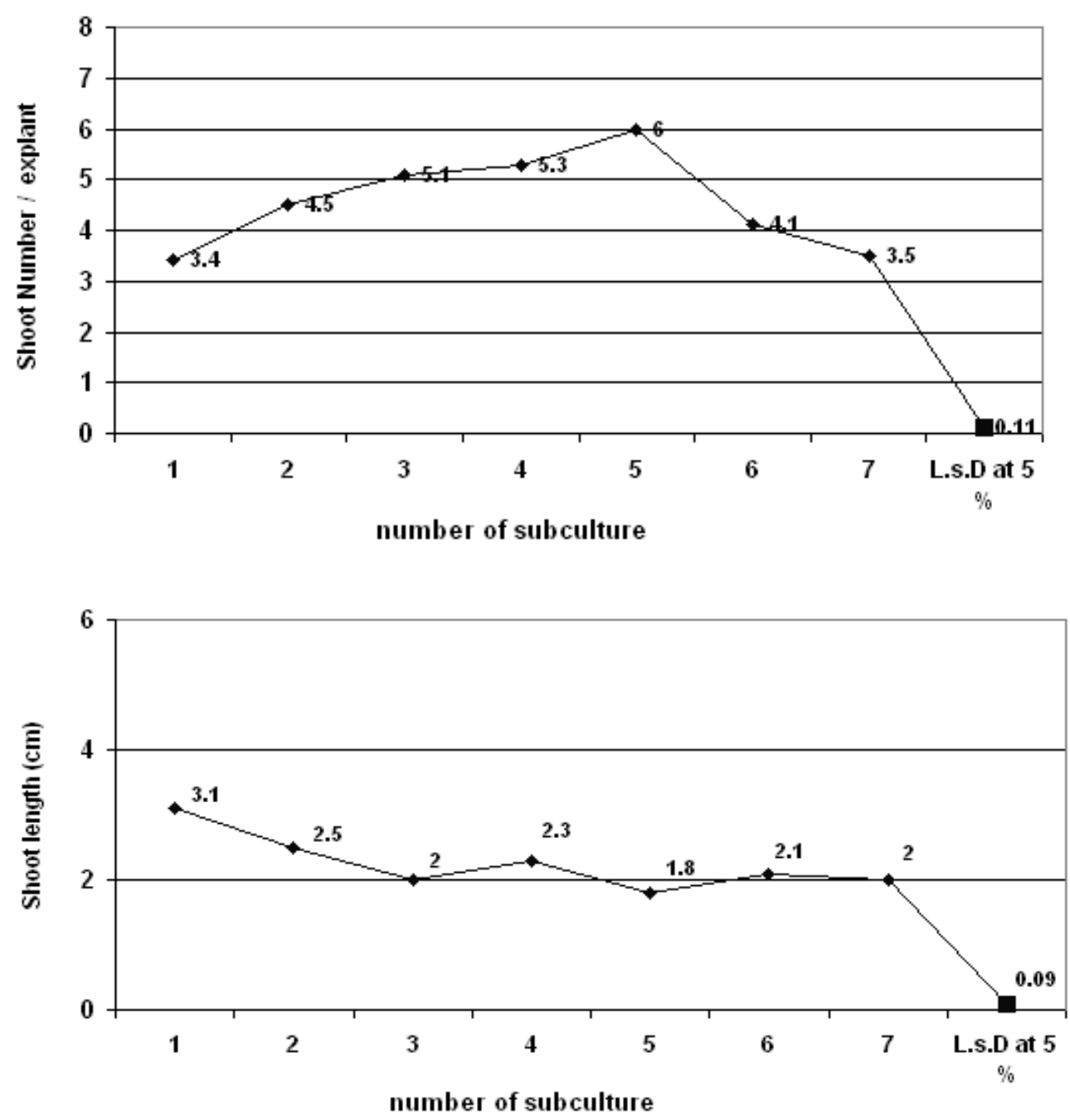

Fig 4. Effect of number of subcultures on the number and length of Shoots production of globe artichoke developed from shoot tip culture. 


\section{B- Root formation \\ a- Effect of auxins}

The estimation of percentage of root formation on globe artichoke shoots culture as affected by IBA and IAA cleared that the two levels of auxins gave rise to the explants up to $100 \%$ for root formation. On the other hand IBA treatments encouraged the root formation (number and length|) than IAA as shown in Fig (5). Similar Results were obtained by Upadhyaya et al (1985). Hartmann and Kester(1983) noted that IBA is most often recommended as a rooting agent because it less phytotoxic over a broader range of concentrations and active in more species than the other auxins such as IAA. On the other side IBA was significantly more stable than IAA to autoclaving so the majority of IAA could be degraded under the same concentration (Scott and Ellen 1990). From another point of view several investigators tried to relate the lower rooting ability of IAA to inhibitory effect of IAA induced ethylene. Mullins (1972) suggested that the promotive effect of auxins on induction of rooting are opposed by the inhibitory effect of auxins induced ethylene. Since IAA is more effective than IBA in inducing ethylene production.

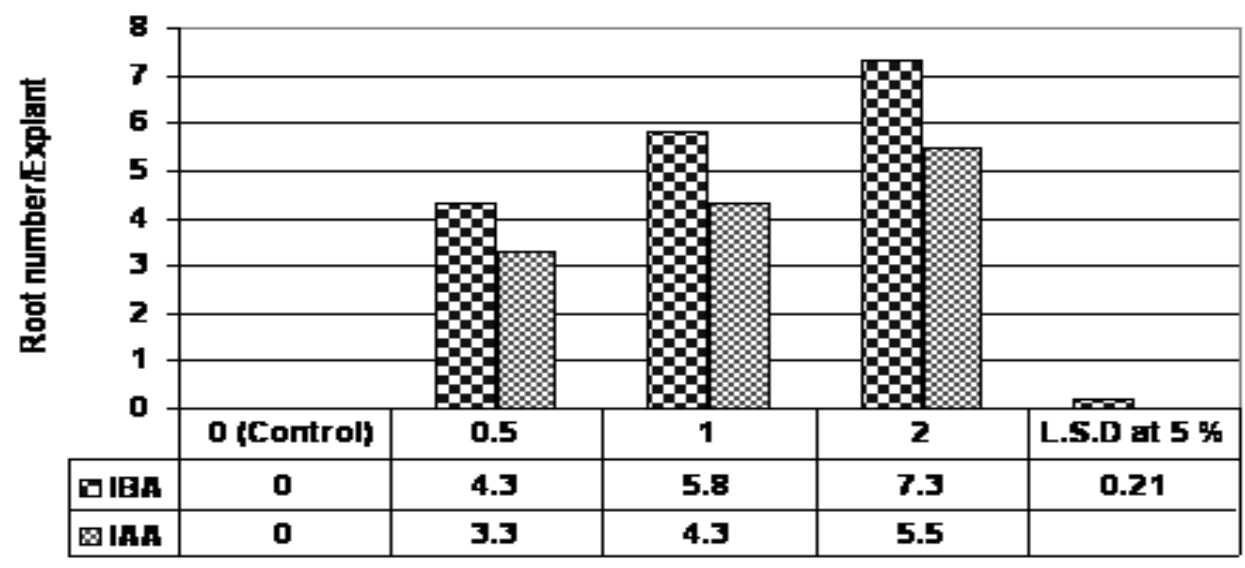

\section{Concentrations (mgh)}

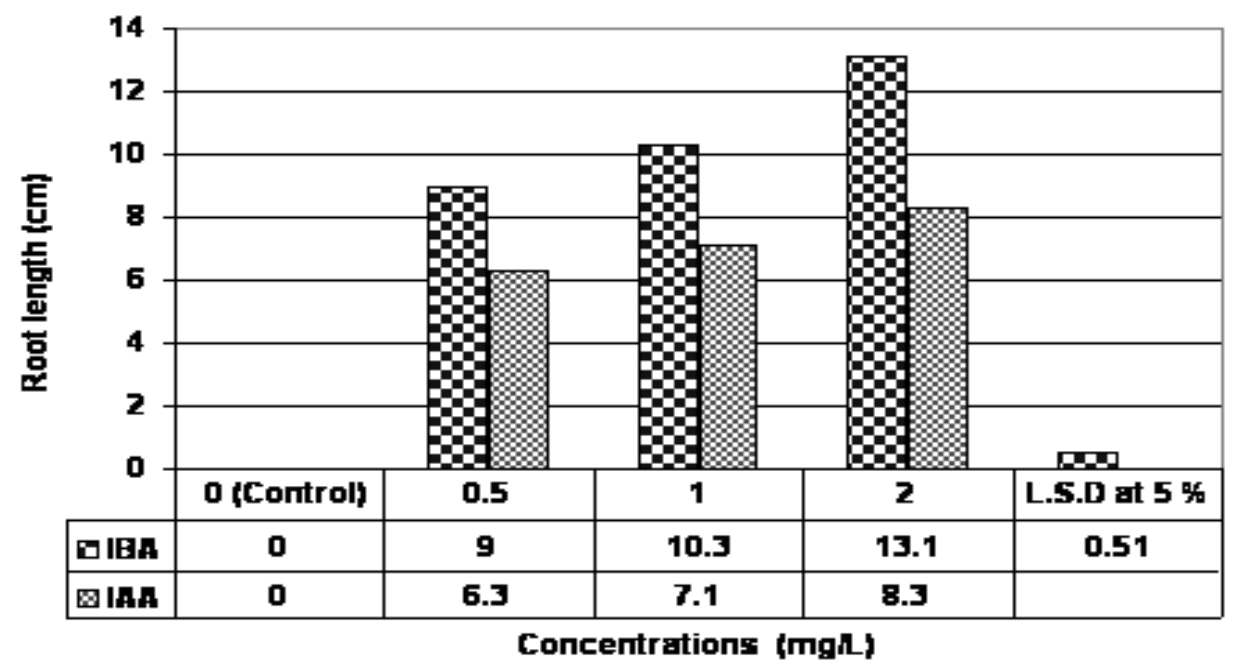

Fig 5. Effect of auxins on root number production of globe artichoke developed from shoot culture. 


\section{c- Effect of activated charcoal}

Data in Fig (6) clear that addition of activated charcoal to the nutrient media is very important for encourage root formation comparing to the media free from activated charcoal. These results were agreement with those results obtained with Bigot and Foury (1984) and Ismaeel (1995) who illustrated that activated charcoal reduced the amount of phenolic browning that occurs in culture.

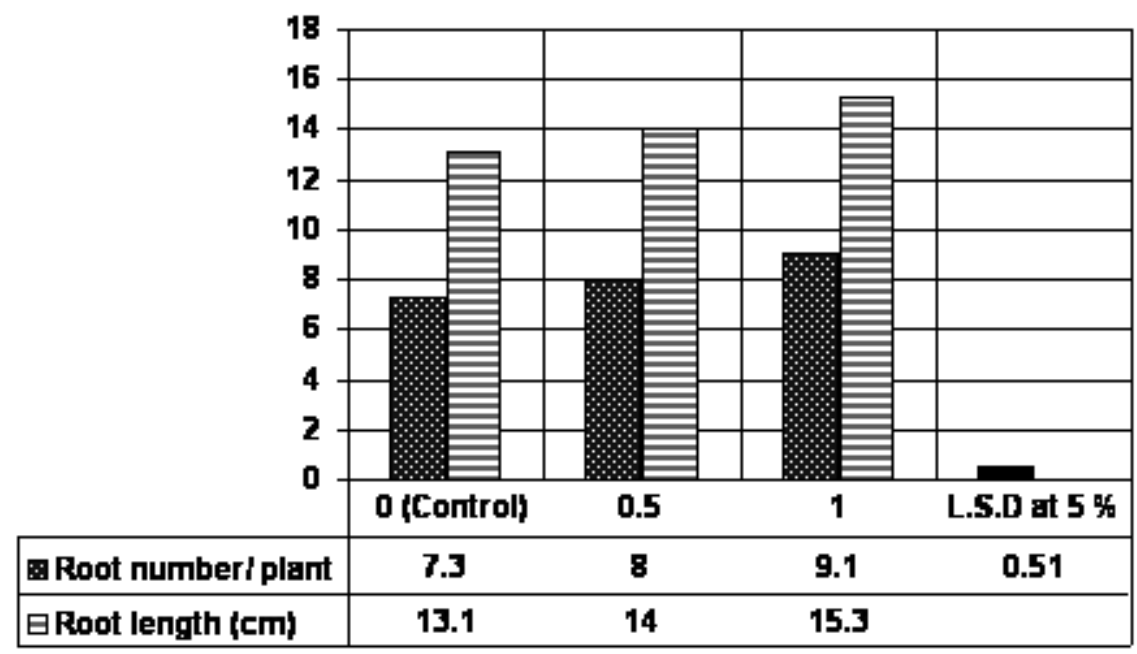

\section{Concentrations (gh)}

Fig 6. Effect of activated charcoal on root length and number of globe artichoke developed from shoots culture.

\section{Second experiment: Acclimatization}

Data in fig (7 and 8 ) reported that media contained vermiculite either alone or in combination with other compounds gave the highest transplants survival percentage ranged $(65-90 \%)$. On the other hand addition sand to the media for growing plantlets reduces the percentage of survival. Same results were happened with the results of Ismail (1995). 


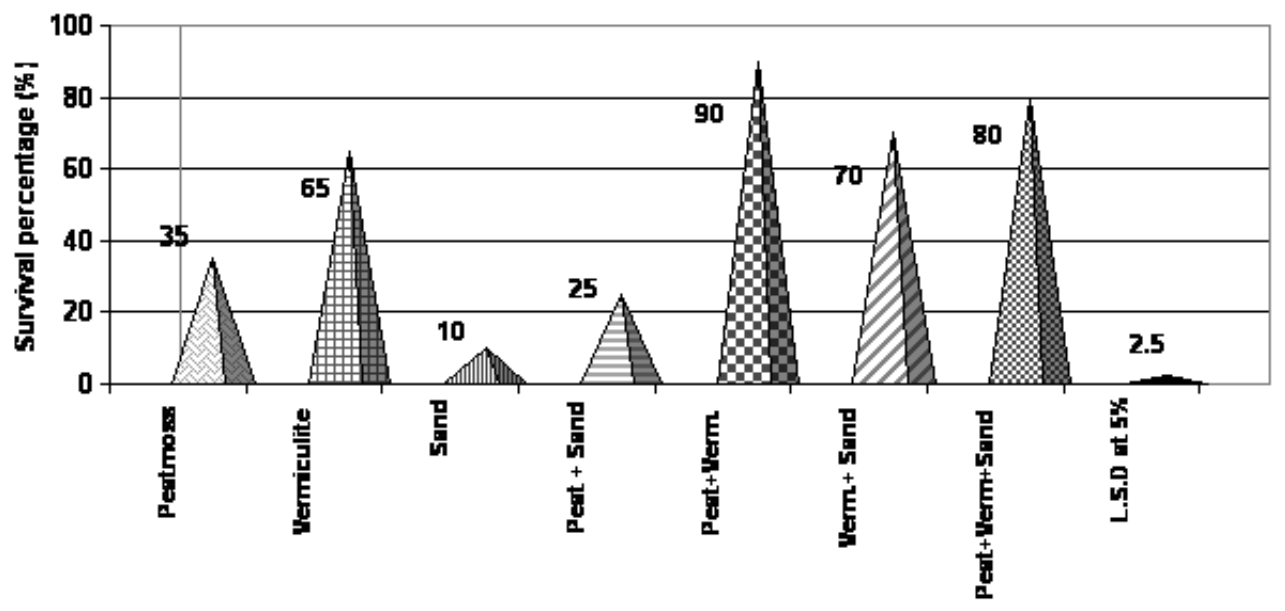

Substrates

Fig 7. Effect of transplanting media on the percentage of survival of plantlets of globe artichoke (after 8 weeks of transplanting.
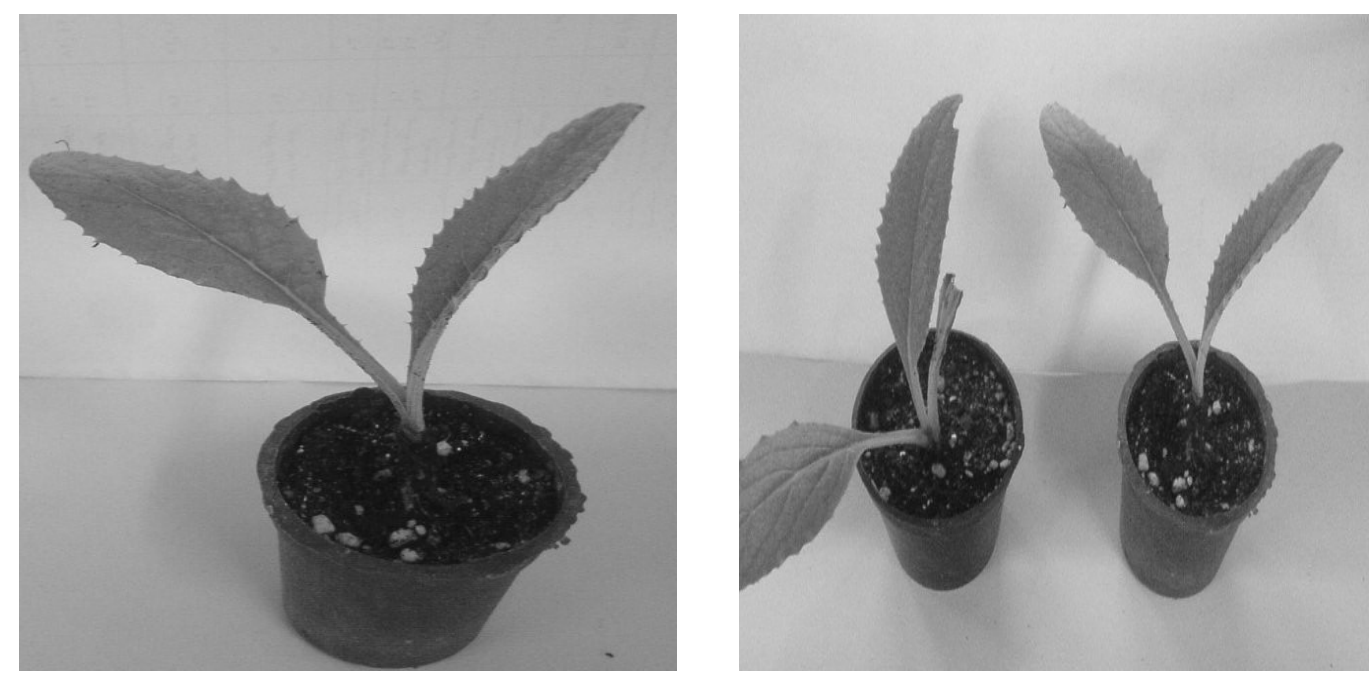

Fig 8. Ex vitro Acclimatized globe artichoke grown in pots containin peat moss and vermiculite. 


\section{REFERENCES}

1. Alphonse M. M.A. Badawi and T.M. Abd-elal. 2002. Preliminary studies on the evaluation of some clones and cultivars of Artichoke. Egypt. J.Hort.29(2)(In press).

2. Ammirato P.V. 1983. Embryogenesis. In: Handbook of Plant Cell Culture (Eds. Evans D.A, W.R.S. Sharp P.V. Ammirato and Y.Y. Amada). PP. 82-123 MacMillan New York.

3. Ancora G. 1986. Globe artichoke (Cynara Scolymus L.). In: Biotechnologey in Agriculture and Foresty. Vol 2: Crops (Ed. Bajaj Y.P.). . Springer-Verlag Berlin PP. 471-484.

4. Ancora G. M.L. Belli-Donni and L. Cuozza. 1981. Globe artichoke plants obtained from shoot apices through rapid in vitro micropropagation. Sci. Hort. 14207.

5. Anderson H.M, A.J. Abbott and S. Wiltshire. 1982. Micropropagation of strawberry plants in vitro. Effect of growth regulators on incidence of multiapex abnormality. Sci. Hort. 16:331-341.

6. Bekheet A. Sh. 1992. in vitro propagation of globe artichoke through tissue culture technique. M.Sc. Thesis Fac. Agric. Ain Shams Uni. Egypt 92 p.

7. Bigot C. and L.Foury 1984.in vitro propagation of globe artichoke (Cynara scolymus L.) from seeds: field comparison of some clones with heir parent lines. Agronomie 4 699.

8. El-Zeiny O.A.H.1997. Tissue culture study on tomato. Ph.D.Thesis Faculty of agric. Al-Azhar Univ.

9. El-Zeiny O.A.H. 2002. Using tissue culture as a tool for increasing the productivity of seedlings and total yield of some pepper hybris. Arab Univ.J.of Agric.Scie.10(1):273 $-285(2002)$

10. Hartmann H.T. and D.E. Kester. 1983. Plant propagation principles and practices. Section 16:4 th Edition Prentice-Hall.Inc. Englewood Cliffs New Jersy.

11. Ibrahim A.M. E.J.Ryder and V.E.Rubatzky 1981. Offshoots vs. stumps as planting materials for globe artichoke. J. Amer. Soc. Hort. Sci. 106 (6) 728.

12. Ismaeel S.A. 1995. Performance of globe artichoke (Cynara scolymusL.) plants developed from tissue culture under low plastic tunnel. M.Sc. Thesis Ain Shams Univ. Egypt 79

13. Lerch K. 1981. In Metal Ions in Biological Systems. (Ed. Sigel. H) pp. 143-186 Marcel Dekker New York.

14. Mehrez G. 1998. Evaluation of some artichoke clones through micropropagation technique. M.Sc. Thesis. Fac. Agric. airo Univ. Egypt 171 p. 
15. Mullins MG. 1972. Auxin and ethylene in adventitious root formation by auxinethylene interaction in pea stem cutting. Physiol.Plant 61:298 - 302.

16. Murashige T. and F.A. Skoog. 1962. A revised medium for rapid growth and bioassays with tobacco tissue cultures. Physiol. Pl. 15: 473-97.

17. Ordas R.J. R. Tavazza and G. Ancora 1990. In vitro morphogenesis in the globe artichoke (Synara scolymus L.). Plant Science. 71 (2): 233-237.

18. Rossi V. and G.De-Paoli. 1992. Micro propagation of artichoke (Cynara scolymus L.). In: Biotechnology in Agriculture and Forestry 19 High. Tech and Micropropagation III (Y.P.S. Bajaj Ed.) pp. 118-134. Springer-verlag Berlin.

19. Snedicor G.W. and W.G.Cochran. 1980. Methods.Sixth EditionIowaState Univ. Press Amer. Iowa. USA..

20. Torres K.C. 1989. Tissue culture media composition and preparation. In: Tissue Culture technique for Horticulture Crop. Cf. Torres (Ed.) pp. 26-51. Van no stand reinhold New Work

21. UpadhyayaA.,S.Narendra, D.J. Weber and B.N.Smith. 1985.In vitro propagation of rubber-producing desert shrub.Hort.Sci.20:864 - 865 .

22. Welbaum G.E. 1994. Annual culture of globe artichoke . from seed in Virginia. Hort. Technology 4 (2): 147-150. 


\section{الإنتاج التجارى للخرشوف معمليا}

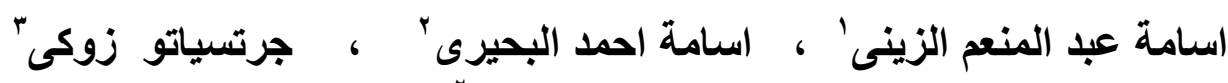

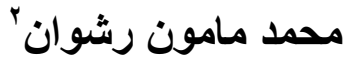

1- اقسام بحوث الخضر - معهُ بحوث البساتين - مركز البحوث الزراعية - الدقى - جيزة- مصر.

$$
\text { r- r- قسم البساتين - كلبة الزراعة - جامعة عين شعس - مصر. }
$$

تم تنفيذ هذا العمل بمعمل زر اعـة الأنسجةـ وحدة بحوث الزراعية بالاراضى القاحلة ، كلية الزر اعة جامعة عين شمس خلال موسمى خريف 7 . . و . . . ب في تجربتين منفصلتين :

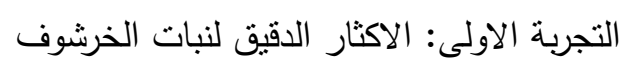

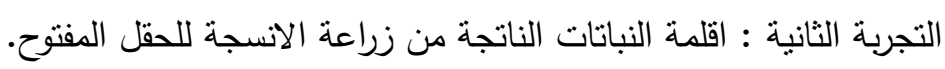

$$
\text { التجربة الاولى: الاكثار الدقيق لنبات الخرشوف : لناته }
$$

اوضحت النتائج ان هناك علاقة بين حجم القمة النامية المنزرعة وكل من نسبة النجاح - عدد الندات

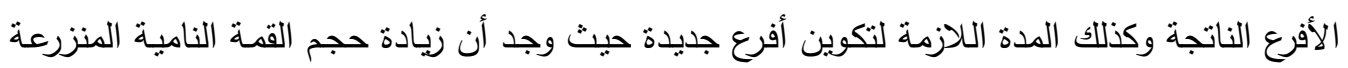

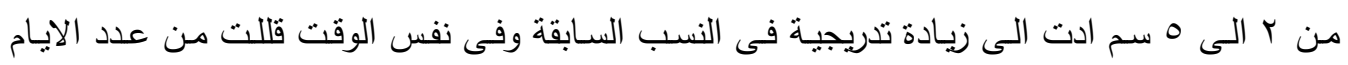
لتكوين افرع جديدة.

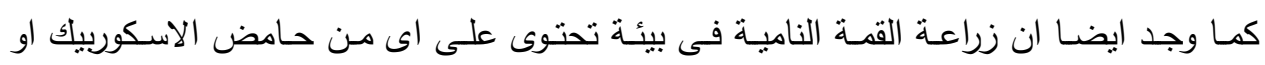

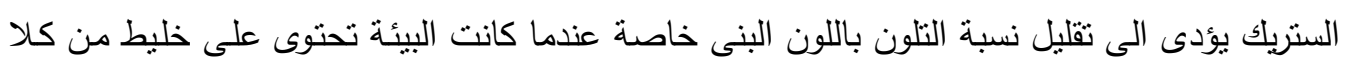
الحامضيين معا. كذلك وجد ايضا ان زيادة مستوى الستوكينينات ( البنزيل ادنين او الكينتين) فى البيئة

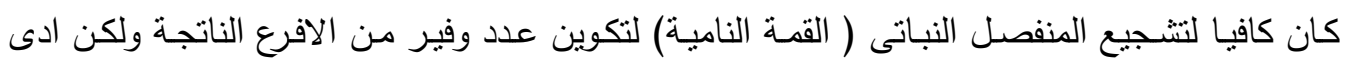
التركيز المرتفع (• ( ملليجرام/ لتر) الى تكوين كلس بجانب الافرع الناتجة.

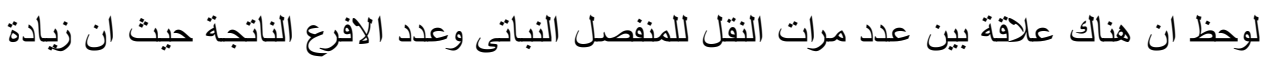
عدد مرات النقل حتى النقلة الخامسة يؤدى الى زيادة عدد الافرع الناتجة.

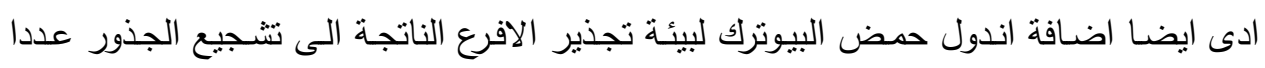

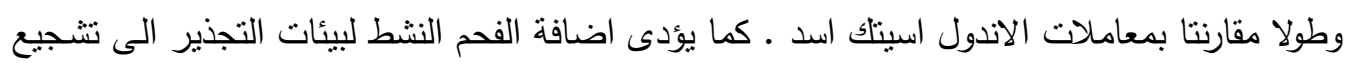

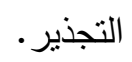
التجربة الثانية: الاقلمة

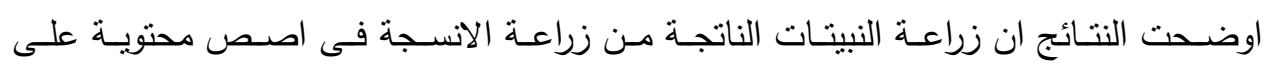

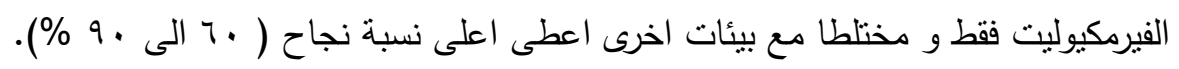

